\title{
Metabolizable energy levels for meat quails from 15 to 35 days of age
}

\author{
Níveis de energia metabolizável para codornas de corte de 15 a 35 dias de idade
}

\author{
Jorge Cunha Lima Muniz ${ }^{I^{*}}$ Sérgio Luiz de Toledo Barreto ${ }^{\mathrm{I}}$ Raquel Mencalha ${ }^{\mathrm{II}}$ \\ Gabriel da Silva Viana ${ }^{I}$ Renata de Souza Reis ${ }^{I I I}$ Cleverson Luís Nascimento Ribeiro ${ }^{I}$ \\ Melissa Izabel Hannas ${ }^{I}$ Luiz Fernando Teixeira Albino ${ }^{I}$
}

\section{ABSTRACT}

This trial was carried out to evaluate the effects of dietetic metabolizable energy levels on performance and carcass traits of meat quails from 15 to 35 days old. Five hundred sixty, 15-d old, meat quails were randomly assigned to five treatments (2.850; 2.950; 3.050; 3.150 e 3.250kcal of $\mathrm{ME} \mathrm{kg}^{-1}$ of diet), with eight replicates and fourteen birds per experimental unit. Feed intake, protein and lysine intake and feed conversion decreased linearly as the metabolizable energy content of diets increased $(P<0.01)$, whereas metabolizable energy intake, body weight, weight gain and viability were not affected $(P>0.05)$ by the treatments. Diets did not influence $(P>0.05)$ carcass traits as dry matter, moisture and protein content in carcass. However a quadratic effect $(P<0.04)$ were observed on carcass fat content. Based on these results, the adequate metabolizable energy level to ensure better

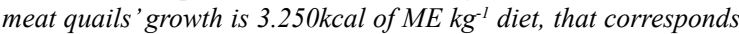
to a metabolizable energy: crude protein ratio of 139,24.

Key words: Coturnix coturnix sp., energy: protein ratio, performance.

\section{RESUMO}

Com o objetivo de avaliar o efeito dos niveis de energia metabolizável (EM) sobre o desempenho de codornas de corte de 15 a 35 dias de idade, foi conduzido um experimento com 560 aves aos 15 dias de idade, distribuidas em delineamento inteiramente casualizado com cinco tratamentos (2.850; 2.950; 3.050; 3.150 e $3.250 \mathrm{kcal}^{\text {de }} \mathrm{EM} \mathrm{kg}^{-1}$ de ração), oito repetições com 14 aves por unidade experimental. Verificou-se redução linear $(P<0,01)$ no consumo de ração, de proteína, de lisina e na conversão alimentar, com o aumento dos níveis de EM da ração. $O$ consumo de energia metabolizável, o peso corporal, o ganho de peso, viabilidade das aves não foram influenciados $(P>0,05)$ pelos níveis de EM utilizados. Os níveis de EM das dietas não influenciaram $(P>0,05)$ a matéria seca, o teor de umidade e a proteina nas carcaças. Foi observado efeito quadrático $(P<0,04)$ dos niveis de EM sobre o teor de gordura nas carcaças. Conclui-

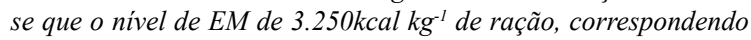
à relação de energia metabolizável:proteína bruta de 139,24, possibilita melhor desempenho das codornas de corte.

Palavras-chave: Coturnix coturnix sp., desempenho, relação energia:proteína.

\section{INTRODUCTION}

In spite of facing several challenges, meat quail industry has been showing positive growth rates of at last decade. In Brazil, meat quail commercialization in industrial scale has started in 1989, after "Perdigão Industrial" company, starts its business with the Avis Raras line, using imported meat-type breeders (PASQUETTI, 2011). Despite the increase in meat quail commercialization, the activity still faces difficulties such as the lack of established genetic meat-type line, and the determination of their nutritional requirements. It's well known that quail performance and carcass traits are influenced by growth phase, genetics, and dietary nutrients intake (KUL et al., 2006); and that birds' growth rate increases with age, until achieving a plateau, when they reach a maximum value with posterior decrease (KESSLER et al., 2000; LONGO, 2000). According to GRIESER et al. (2015), from 14 days of age on, meat-type quail growth rate becomes decreasing,

\footnotetext{
IDepartamento de Zootecnia, Universidade Federal de Viçosa (UFV), 36570-000, Viçosa, MG, Brasil. E-mail: jorge.limamuniz@hotmail.com.br. ${ }^{*}$ Corresponding author.

"Universidade Federal de Lavras (UFLA), Lavras, MG, Brasil.

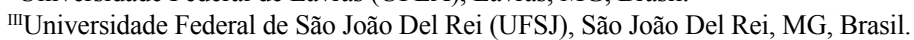


which influence negatively on feed conversion rate. Considering such behavior in quail growth, associated to the fact that at 35 days of age quail carcass already presents adequate commercial size, it is recommended to slaughter birds at this age.

The supply of metabolizable energy in quail diet is essential to ensure adequate productive performance, especially after 14 days of age, due to the increased energy requirement resultant from its increased body size (TON, 2007; OLIVEIRA et al., 2007). Dietary energy supply is essential for animal performance, since energetic content of diets regulates feed intake, which consequently reflects on birds' performance (BARRETO et al., 2007). Both excess and reduction on feed intake may result in deleterious effects on animal performance and increase feed costs. Although the effects of dietary energy content on broiler performance are well known, few data involving meat quails metabolizable energy requirements are available in literature.

Beyond few literature data, discrepancies observed among published reports, most probably caused by nutritional requirements used as base for diets formulation, become unclear the birds' energy requirements. Thus this study was performed to determinate the effects of different levels of metabolizable energy on meat quails performance and carcass traits from 15 to 35 days of age.

\section{MATERIALS AND METHODS}

A total of 560 one day old quails were housed and fed with a diet formulated based on the nutritional recommendations described by SILVA \& COSTA (2009) until 14 days of age.

At the beginning of the trial, at 15 days of age, birds (with average weight of $90.64 \mathrm{~g}$ ) were randomly assigned to experimental treatments, each one replicated eight times with fourteen birds per experimental unit. Experimental diets (Table 1) were formulated according to nutritional requirements described by SILVA \& COSTA (2009). To formulated diets it was considered the chemical composition of ingredients described by ROSTAGNO et al. (2011). The treatments consisted of different metabolizable energy levels $(2,850,2,950,3,050,3,150$, and $\left.3,250 \mathrm{kcal} \mathrm{kg}^{-1}\right)$. Birds were housed in $50 \times 50 \times 5 \mathrm{~cm}$ (width $\times$ length $\times$ height) metal cages placed on masonry counter tops with approximately $120 \mathrm{~cm}$ in height. Each cage was equipped with one nipple drinker and one metal feeder placed in front of each cage. Immediately after housing into the cages, the quails were oriented for the presence of water by wetting their beak into the water inside nipples cup. The lighting program consisted of $24 \mathrm{~h}$ of light (natural + artificial). The environmental temperature inside the experimental facility was recorded by a maximum and minimum thermometer, and the relative humidity of the air was determined by dry and wet bulb thermometers, both of them birds height placed. Quails behavior around the lamps was also considered in temperature control.

At the end of the trial, at 35 days of age, birds and the residual feed in feeders were weighed to calculate the following performance parameters: feed intake (g), metabolizable energy intake (kcal), crude protein intake $(\mathrm{g})$, lysine intake $(\mathrm{g})$, body weight $(\mathrm{g})$, weight gain $(\mathrm{g})$, feed conversion $\left(\mathrm{g} \mathrm{g}^{-1}\right)$. Viability $(\%)$ was calculated through the difference between birds alive at the end and the beginning of the trial. After 4 hours of fasting, two birds per experimental unit were weighed to obtain their live weight, and then slaughtered by cervical dislocation between the atlas and the occipital bone. After the slaughter, birds were stored into plastic bags identified per treatment and replicated and immediately frozen. Then, frozen samples were ground in industrial meat grinder to determinate carcass composition. The ground carcasses were weighed, homogenized, and dried in a forced-ventilation oven at $55^{\circ} \mathrm{C}$ for $72 \mathrm{~h}$ for predrying. Afterwards, it were ground in a ball mill and transferred to the Animal Nutrition Laboratory of DZO for the analyses of the dry matter (DM), moisture $(\mathrm{M})$, crude protein $(\mathrm{CP})$, and fat (EE) contents in the carcasses, according to the methodology described by SILVA \& QUEIRÓZ (2004). Statistical analyses were performed using Sistema para Análises Estatísticas (SAEG, 2007) software package. After analysis of variance, metabolizable energy requirement was estimated using polynomial regression model. Significant effects were considered for $\mathrm{P}$-value $\leq 0,05$.

\section{RESULTS AND DISCUSSION}

The average maximum and minimum temperatures recorded during the trial (from 15 to $35 \mathrm{~d}$ of age) were $31.99 \pm 2.7^{\circ} \mathrm{C}$ and $22.70 \pm 1.3^{\circ} \mathrm{C}$, respectively. Thus, based on the comfort temperatures (between 32 and $22^{\circ} \mathrm{C}$ ) suggested by MURAKAMI \& GARCIA (2010), it can be inferred that the birds were under thermal comfort during the experimental period.

The birds' feed intake decreased linearly $(\mathrm{P}<0.01)$ with the increase in the dietary ME levels; however, no effects were observed $(\mathrm{P}>0.05)$ on $\mathrm{ME}$ intake. According to regression equation presented at table 2 , each $100 \mathrm{kcal}$ of increase in dietary energy 
Table 1 - Chemical and nutritional composition of experimental diets on natural matter.

\begin{tabular}{|c|c|c|c|c|c|}
\hline Ingredient & 2,850 & 2,950 & 3,050 & 3,150 & 3,250 \\
\hline Corn $(7.88 \%)$ & 40.560 & 40.560 & 40.560 & 40.560 & 40.560 \\
\hline Soybean meal (48\%) & 31.831 & 31.831 & 31.831 & 31.831 & 31.831 \\
\hline Inert (sand) & 5.000 & 3.853 & 2.715 & 1.577 & 0.440 \\
\hline Sorghum & 12.000 & 12.000 & 12.000 & 12.000 & 12.000 \\
\hline Corn gluten $(60 \%)$ & 6.154 & 6.154 & 6.154 & 6.154 & 6.154 \\
\hline Soybean oil & 1.589 & 2.727 & 3.865 & 5.002 & 6.140 \\
\hline Limestone & 1.018 & 1.018 & 1.018 & 1.018 & 1.018 \\
\hline Dicalcium phosphate & 0.878 & 0.878 & 0.878 & 0.878 & 0.878 \\
\hline Salt & 0.334 & 0.334 & 0.334 & 0.334 & 0.334 \\
\hline DL-methionine (99\%) & 0.145 & 0.145 & 0.145 & 0.145 & 0.145 \\
\hline L-arginine (99\%) & 0.151 & 0.151 & 0.151 & 0.151 & 0.151 \\
\hline Choline chloride (60\%) & 0.100 & 0.100 & 0.100 & 0.100 & 0.100 \\
\hline Mineral premix ${ }^{1}$ & 0.070 & 0.070 & 0.070 & 0.070 & 0.070 \\
\hline Vitamin premix ${ }^{2}$ & 0.100 & 0.100 & 0.100 & 0.100 & 0.100 \\
\hline Antioxidant $^{3}$ & 0.010 & 0.010 & 0.010 & 0.010 & 0.010 \\
\hline Growth promoter ${ }^{4}$ & 0.010 & 0.010 & 0.010 & 0.010 & 0.010 \\
\hline Coccidiostatic $^{5}$ & 0.060 & 0.060 & 0.060 & 0.060 & 0.060 \\
\hline Total & 100.000 & 100.000 & 100.000 & 100.000 & 100.000 \\
\hline Metabolizable energy $\left(\mathrm{kcal} \mathrm{kg}^{-1}\right)$ & 2,850 & 2,950 & 3,050 & 3,150 & 3,250 \\
\hline Crude protein (\%) & 23.34 & 23.34 & 23.34 & 23.34 & 23.34 \\
\hline Digestible lysine (\%) & 1.016 & 1.016 & 1.016 & 1.016 & 1.016 \\
\hline Digestible met + cys (\%) & 0.822 & 0.822 & 0.822 & 0.822 & 0.822 \\
\hline Digestible threonine (\%) & 0.783 & 0.783 & 0.783 & 0.783 & 0.783 \\
\hline Digestible tryptophan (\%) & 0.243 & 0.243 & 0.243 & 0.243 & 0.243 \\
\hline Calcium (\%) & 0.702 & 0.702 & 0.702 & 0.702 & 0.702 \\
\hline Available phosphorous (\%) & 0.274 & 0.274 & 0.274 & 0.274 & 0.274 \\
\hline
\end{tabular}

${ }^{1}$ Composition $\mathrm{kg}^{-1}$ of product: Manganese: $160 \mathrm{~g}$, Iron: $100 \mathrm{~g}$, Zinc: $100 \mathrm{~g}$, Copper: $20 \mathrm{~g}$, Cobalt: $2 \mathrm{~g}$, Iodine: $2 \mathrm{~g}$, Inert: $1,000 \mathrm{~g}$. ${ }^{2}$ Composition/kg of product: Vit. A:12,000,000UI., Vit D3:3,600,000UI., Vit. E: 3,500UI., VitB1:2,500mg, Vit B2: 8,000mg, Vit B6:5,000mg, Pantothenic acid: 12,000mg, Biotin: $200 \mathrm{mg}$, Vit. K: 3,000mg, Folic acid: 1,500mg, Nicotinic acid: 40,000mg, Vit. B12: 20,000mg, Selenium: 150mg, Inert: 1,000g. ${ }^{3}$ Butil-hidroxy-tolueno. ${ }^{4}$ Avilamicin. ${ }^{5}$ Coxistac $12 \%$.

level decreased by approximately $15 \mathrm{~g}$ in birds' feed intake. Animals regulate feed intake in an attempt to ingest a constant amount of energy, changing intake according to the level of energy (LEESON et al., 1996). According to FREITAS et al. (2006), this occurs because meat quails feed primarily to meet their energy requirements, which is a similar behavior to that of broiler hens. These results are in agreement in those reported by VELOSO et al. (2012), SCHERER (2011), and TON et al. (2011), who observed a decrease in feed intake with the increase on ME level of in diets for meat quails at 35 days of age.

The increase in the ME levels resulted in linear reduction $(\mathrm{P}<0.01)$ in protein and lysine intake. However, ME levels did not affect $(\mathrm{P}>0.05)$ birds' body weight or weight gain. These results may be related to the increased birds' capacity of digestion and absorption with age advancing and the increasing inclusion of oil in experimental diets. According to SAKOMURA et al. (2004), the oil exert an effect known as extra caloric, that increases digesta retention time in the gastrointestinal tract (GAT), what consequently increases the nutrients availability in GAT lumen. Similar results were observed by TON et al. (2011), who did not observe effect of the ME levels (2,800 to $\left.3,100 \mathrm{kcal} \mathrm{kg}^{-1}\right)$ on body weight or weight gain of meat quails from 4 to 35 days of age. CORRÊA et al. (2007b) also did not observe any effects of the dietary ME levels $\left(2,900\right.$ and 3,100 $\left.\mathrm{kcal} \mathrm{kg}^{-1}\right)$ on these same parameters on meat quails aged from 22 to 42 days. Conversely, TEIXEIRA et al. (2013) observed a linear increase in meat-type quails weight gain from 1 to $35 \mathrm{~d}$ age after ranging metabolizable energy levels from 2,700 a $3,100 \mathrm{kcal}^{-1}$. 
Table 2 - Feed intake (FI), metabolizable energy intake (MEI), crude protein intake (CPI), lysine intake (LYSI), body weight (BW), weight gain (WG), feed conversion (FC) and viability (VIAB) of meat-type quails from 15 to 35 days old fed different metabolizable energy levels.

\begin{tabular}{|c|c|c|c|c|c|c|c|c|c|c|c|}
\hline \multirow{2}{*}{ Variables } & \multicolumn{10}{|c|}{ - } & \multirow{2}{*}{$\mathrm{CV}(\%)$} \\
\hline & 2,850 & $\mathrm{SE}^{2}$ & 2,950 & $\mathrm{SE}^{2}$ & 3,050 & $\mathrm{SE}^{2}$ & 3,150 & $\mathrm{SE}^{2}$ & 3,250 & $\mathrm{SE}^{2}$ & \\
\hline FI $\left(\mathrm{g} \mathrm{bird}^{-1}\right)^{3}$ & 483.79 & 5.36 & 468.85 & 4.55 & 453.56 & 4.47 & 437.59 & 4.62 & 423.96 & 4.07 & 2.89 \\
\hline MEI (kcal) $)^{4}$ & $1,378.80$ & 15.28 & $1,383.12$ & 13.43 & $1,383.35$ & 13.64 & $1,378.40$ & 14.57 & $1,377.87$ & 13.22 & 2.87 \\
\hline $\mathrm{CPI}(\mathrm{g})^{3}$ & 112.91 & 1.25 & 109.43 & 1.06 & 105.86 & 1.04 & 102.13 & 1.08 & 98.95 & 0.95 & 2.89 \\
\hline $\operatorname{LYSI}(\mathrm{g})^{3}$ & 4.97 & 0.06 & 4.82 & 0.05 & 4.66 & 0.05 & 4.50 & 0.05 & 4.36 & 0.04 & 2.89 \\
\hline $\mathrm{BW}(\mathrm{g})^{4}$ & 250.51 & 2.63 & 250.93 & 2.01 & 249.74 & 3.13 & 248.17 & 2.87 & 248.62 & 2.00 & 2.09 \\
\hline WG $(g)^{4}$ & 159.60 & 2.44 & 160.36 & 2.28 & 159.44 & $3 . .26$ & 157.87 & 2.96 & 157.75 & 2.09 & 4.70 \\
\hline $\mathrm{FC}\left(\mathrm{g} \mathrm{g}^{-1}\right)^{3}$ & 3.03 & 0.03 & 2.93 & 0.03 & 2.85 & 0.04 & 2.78 & 0.03 & 2.69 & 0.02 & 3.07 \\
\hline VIAB $(\%)^{4}$ & 99.04 & 0.96 & 99.04 & 0.96 & 100 & 0.00 & 99.04 & 0.96 & 100 & 0.00 & 2.12 \\
\hline \multicolumn{6}{|c|}{$\mathrm{FI}=913.860-0.150921 \mathrm{ME}$} & \multicolumn{3}{|c|}{$\mathrm{NE}^{5} \geq 3,250$} & & \multicolumn{2}{|c|}{$\mathrm{R}^{2}=0.75$} \\
\hline \multicolumn{6}{|c|}{$\mathrm{CPI}=213.297-0.0352256 \mathrm{ME}$} & \multicolumn{3}{|c|}{$\mathrm{NE}^{5} \geq 3,250$} & & \multicolumn{2}{|c|}{$\mathrm{R}^{2}=0.75$} \\
\hline \multicolumn{6}{|c|}{$\mathrm{LYSI}=9.39456-0.0015515 \mathrm{ME}$} & \multicolumn{3}{|c|}{$\mathrm{NE}^{5} \geq 3,250$} & & \multicolumn{2}{|c|}{$\mathrm{R}^{2}=0.75$} \\
\hline \multicolumn{6}{|c|}{$\mathrm{FC}=5.41591-0.000839750 \mathrm{ME}$} & \multicolumn{2}{|c|}{$\mathrm{NE}^{5} \geq 3,250$} & & & \multicolumn{2}{|c|}{$\mathrm{R}^{2}=0.67$} \\
\hline
\end{tabular}

${ }^{1}$ Coefficient of variation; ${ }^{2}$ Standard error; ${ }^{3}$ Linear effect; ${ }^{4}$ Not significant; ${ }^{5}$ Estimated level; $\mathrm{R}^{2}=$ Total sum of squares/Sum of squares of treatment.

Feed conversion decreased linearly $(\mathrm{P}<0.01)$ as the dietary ME level was increased. According to the equation presented in table 2, for every increase in $100 \mathrm{kcal}$ of dietary ME, feed conversion was improved by approximately 0.1 point. A similar response was observed by SCHERER (2009), who obtained a reduction of 0.1 point in feed conversion as a result of an increase from 2,800 to $3,300 \mathrm{kcal} \mathrm{kg}^{-1}$ in the ME level of diets for broilers from 15 to 35 days of age. Similar effects were verified by CORREAA et al. (2007a), who reported that the increase in ME from 2,900 to $3,100 \mathrm{kcal} \mathrm{kg}^{-1}$ provided better quails' feed conversion in the phases of 15 to 21,22 to 28,29 to 35 , and 46 to 42 days of age. The feed conversion values depends on feed intake and weight gain. As mentioned previously, the increase in the ME levels reduced feed intake, but did not influence the weight gain, which explains the behavior observed in feed conversion values from the increase in the dietary ME.

Birds' viability was not affected by dietary ME levels $(\mathrm{P}>0.05)$. During experimental phase only three animals died, corresponding to a mortality rate of $0.54 \%$. Higher values were described by FREITAS et al. (2006) and OLIVEIRA (2001), who observed mortality rates of 2.08 and $3.3 \%$, respectively for meat quails.

Dietary ME didnot affect $(\mathrm{P}>0.05)$ dry matter, moisture, or protein contents of the quails' carcasses at 35 days of age (Table 3 ). This result is in agreement with the reports of CORRÊA (2006), who did not find effects of the ME levels $(2,900$ and 3,100$)$ on dry matter or crude protein content of quails' carcasses at 42 days of age. According to SILVA et al. (2007), meat quails has a fast growth until 21 days of age, with greater deposition of protein and water in the carcass, quickly reaching $200 \mathrm{~g}$, which is around 25 times their initial weight. After this age, their weight gain declined, due to the greater deposition of fat and retention of nutrients in the reproductive tract.

LEESON (1995) stated that the efficiency in body's protein utilization is reduced because the muscle synthesis is genetically controlled, and thus there is a limit to the daily deposition of this nutrient, irrespective of its intake. However, the extra caloric effect caused by oil in the diets with the higher ME level should be taken into account, as it increases the digestibility of the dietary nutrients, off setting the reduction in the intake of protein and lysine by the birds.

A quadratic effect $(\mathrm{P}<0.04)$ of $\mathrm{ME}$ levels was observed on the fat content (EE) of the birds' carcasses, which, according to the equation, indicates that the level of $2,926 \mathrm{kcal} \mathrm{kg}^{-1}$ showed the lowest estimate, of $11.31 \% \mathrm{EE}$. These results are in agreement with those reported by MEZA et al. (2015), who verified a linear decrease in broilers carcass fat content after ranging dietary metabolizable energy from 3,660 to $3,000 \mathrm{kcal}^{\mathrm{kg}^{-1}}$. 
Table 3 - Dry matter (DM), Moisture (MO), ether extract (EE) and crude protein (CP) content on meat-type quails carcass at 35 days old fed different metabolizable energy levels idem 1.

\begin{tabular}{|c|c|c|c|c|c|c|c|c|c|c|c|}
\hline \multirow{2}{*}{ Variables $^{1}$} & \multicolumn{10}{|c|}{-Metabolizable energy level $\left(\mathrm{kcal} \mathrm{kg}^{-1}\right)$} & \multirow{2}{*}{$\mathrm{CV}(\%)^{2}$} \\
\hline & 2,850 & $\mathrm{SE}^{3}$ & 2,950 & $\mathrm{SE}^{3}$ & 3,050 & $\mathrm{SE}^{3}$ & 3,150 & $\mathrm{SE}^{3}$ & 3,250 & $\mathrm{SE}^{3}$ & \\
\hline $\mathrm{DM}(\%)^{4}$ & 32.11 & 0.88 & 32.28 & 0.51 & 31.96 & 0.31 & 32.74 & 0.49 & 32.46 & 0.34 & 3.36 \\
\hline MO $(\%)^{4}$ & 67.89 & 0.88 & 67.72 & 0.51 & 68.04 & 0.31 & 67.26 & 0.49 & 67.54 & 0.34 & 1.60 \\
\hline $\mathrm{EE}(\%)^{5}$ & 11.32 & 0.13 & 11.40 & 0.14 & 11.30 & 0.10 & 11.67 & 0.06 & 11.94 & 0.05 & 2.51 \\
\hline $\mathrm{CP}(\%)^{4}$ & 15.87 & 0.16 & 16.11 & 0.12 & 16.55 & 0.25 & 16.28 & 0.15 & 16.21 & 0.23 & 3.32 \\
\hline \multicolumn{7}{|c|}{$\mathrm{EE}=63.9249-0.0359552 \mathrm{ME}+0.00000614286 \mathrm{ME}^{2}$} & \multicolumn{3}{|c|}{$\mathrm{EL}^{6}=2,926$} & \multicolumn{2}{|c|}{$\mathrm{R}^{2}=0.73$} \\
\hline
\end{tabular}

${ }^{1}$ Values based on dry matter; ${ }^{2}$ Coefficient of variation; ${ }^{3}$ Standard error; ${ }^{4}$ Not significant; ${ }^{5}$ Quadratic effect; ${ }^{6}$ Estimated level; $\mathrm{R}^{2}=\mathrm{Total}$ sum of squares/Sum of squares of treatment.

Opposite results were reported by SAKOMURA et al. (2004), who evaluated the effect of the dietary ME level on the performance and energy metabolism of broiler hens from 22 to 42 days of age and observed that the birds fed with the diet containing $3,200 \mathrm{kcal} \mathrm{kg}^{-1}$ showed a lower fat content as compared with those that received a low-energy diet, with 3,050 kcal kg-1. TON et al. (2011) observed a linear increase in $35 \mathrm{~d}$ meat quails' carcasses' fat content as the dietary ME levels increased. These results may be related to the greater or lower intake of nutrients by the birds, what promote differences in the lipogenesis rates and consequently changes in carcass composition towards gains in both protein and fat (KESSLER et al., 2000).

According to WALDROUP (1996), the energy: protein ratio also exert an influence on the EE content of carcasses, given that, as this ratio is increased, the amount of deposited fat also increases, especially abdominal fat. According to MENDONÇA et al. (2007), the amount of deposited fat is directly proportional to the quantity of energy available for the synthesis; therefore, surplus dietary energy is well correlated with the deposition of lipids in most animals.

\section{CONCLUSION}

The metabolizable energy level of $3,250 \mathrm{kcal} \mathrm{kg}^{-1}$, which corresponds to the metabolizable energy:crude protein ratio of 139.24 , provides better performance to meat quails from 15 to 35 days of age.

\section{BIOETHICS AND BIOSSECURITY COMMITTEE APPROVAL}

The experimental procedure is registered under protocol no. 37/2012, approved by the Ethics Committee on the Use of Animals of the Department of Animal Science of Universidade Federal de Viçosa (UFV), Minas Gerais, Brazil.

\section{REFERENCES}

BARRETO, S.L.T. et al. Effects of dietary energy levels on the performance and quality of European quails in the initial laying phase. Revista Brasileira de Zootecnia, v.36, n.1, p.86-93, 2007. Available from: <http://www.scielo.br/scielo.php?pid=S151635982007000100011\&script=sci_arttext $>$. Accessed: Jan. 13, 2013. doi: 10.1590/S1516-35982007000100011.

CORRÊA, G.S.S. Exigências nutricionais de diferentes grupos genéticos de codornas de corte. 2006. 175f. Tese (Doutorado em Ciência animal) - Curso de Pós-graduação em Zootecnia, Universidade Federal de Minas Gerais, MG.

CORRÊA, G.S.S. et al. Exigências de proteína bruta e energia metabolizável em codornas de corte durante a fase de crescimento. Arquivo Brasileiro de Medicina Veterinária e Zootecnia, v.59, n.2, p.488-494, 2007a. Available from: <http://www.scielo.br/ pdf/abmvz/v59n2/32.pdf>. Acessed: Jan. 02, 2013. doi: 10.1590/ S0102-09352007000200032.

CORRÊA, G.S.S. et al. Exigência de proteína bruta e energia metabolizável para codornas de corte EV1. Arquivo Brasileiro de Medicina Veterinária e Zootecnia, v.59, n.3, p.797-804, 2007b. Available from: <http://www.scielo.br/pdf/abmvz/v59n3/ a35v59n3.pdf>. Accessed: Feb. 05, 2013. doi: 10.1590/S010209352007000300035 .

FREITAS, A.C. et al. Níveis de proteína bruta e energia metabolizável na ração para codornas de corte. Revista Brasileira de Zootecnia, v.35, n.4, p.1705-1710, 2006. Available from: $<$ http://www.scielo.br/pdf/rbz/v35n4s0/a18v354s.pdf $>$. Accessed: Feb. 03, 2013. doi: 10.1590/S1516-35982006000600018.

GRIESER, D.O. et al. Comparison of growth curve parameters of organs and body components in meat - (Coturnix coturnix coturnix) and laying-type (Coturnix coturnix japonica) quail show interactions between gender and genotype. British Poultry Science, v.56, p.6-14, 2015. Available from: $<$ http://www.tandfonline.com/doi/abs/10.1080/00071668.20 14.988602\#.VfYWixFViko>. Accessed: Sept. 13, 2015. doi: 10.1080/00071668.2014.988602. 
KESSLER, A.M. et al. Manipulação da quantidade de gordura na carcaça de frangos. In: CONFERÊNCIA APINCO DE CIÊNCIA E TECNOLOGIA AVÍCOLAS, 2000, Campinas, SP. Anais... Campinas: Fundação Apinco de Ciência e Tecnologia Avícolas, 2000. V.1, 256p. p.123.

KUL, S. et al. Effect of separate and mixed rearing according to sex on fattening performance and carcass characteristics in Japanese quails (Coturnix coturnix japonica). Archiv Tierzucht, v.49, n.6, p.607-614, 2006. Available from: $<$ http:// archtierz.fbn-dummerstorf.de/pdf/2006/at06p607.pdf $>$. Accessed: Jan. 20, 2013

LEESON, S. Nutrição e qualidade de carcaça de frangos de corte. In: CONFERÊNCIA APINCO DE CIÊNCIA E TECNOLOGIA AVÍCOLAS, 1995, Curitiba, PR. Anais... Curitiba: Fundação Apinco de Ciência e Tecnologia Avícolas, 1995. 149p. p.17.

LEESON, S. et al. Broiler response to energy or energy and protein dilution in the finisher diet. Poultry Science, v.75, p.522-528, 1996. Available from: <http://ps.oxfordjournals.org/content/75/4/522. long>. Accessed: Jan. 27, 2013. doi: 10.3382/ps.0750522.

LONGO, F.A. Estudo do metabolismo energético e do crescimento de frangos de corte. 2000. 76f. Dissertação (Mestrado em Zootecnia) - Curso de Pós-graduação em Zootecnia, Universidade Estadual Paulista, SP.

MENDONÇA, M.O. et al. Níveis de energia metabolizável e relações energia:proteína para aves de corte de crescimento lento criadas em sistema semiconfinado. Acta Scientiarum. Animal Sciences, v.29, n.1, p.23-30, 2007. Available from: $<$ http://www. redalyc.org/pdf/3031/303126486004.pdf >. Accessed: Jan. 25, 2013. doi: 10.1590/S1516-35982008000800014.

MEZA, S.K.L. et al. Níveis de energia metabolizável e lisina digestível sobre a composição e rendimento de carcaça de frangos de corte. Semina, v.36, n.2, p.1079-1090, 2015. Available from: <http://www. uel.br/revistas/uel/index.php/semagrarias/article/view/16217/pdf 647>. Accessed: Sept. 13, 2015. doi: 10.5433/1679-0359.2015v36n2p1079.

MURAKAMI, A.E.; GARCIA, E.R.M. Manejo de codornas de postura. In: SIMPÓSIO INTERNACIONAL COTURNICULTURA, 4., 2010, Lavras, MG. Anais... Lavras: Universidade Federal de Lavras/NECTA, 2010. V.1, 285p. p.38.

OLIVEIRA, E.G. Pontos críticos no manejo e nutrição de codornas. In: SIMPÓSIO SOBRE MANEJO E NUTRIÇÃO DE AVES E SUÍNOS E TECNOLOGIA DA PRODUÇÃO DE RAÇÕES, 2001, Campinas, SP. Anais... Campinas: Colégio Brasileiro de Nutrição Animal, 2001. 360p. p.80.

OLIVEIRA, N.T.E. et al. Determinação da energia metabolizável de diferentes alimentos testados em codornas japonesas fêmeas. Arquivo Brasileiro de Medicina Veterinária e Zootecnia, v.59, p.210-217, 2007. Available from: <http://www.scielo.br/pdf/ abmvz/v59n1/34.pdf>. Accessed: Mar. 17, 2013. doi: 10.1590/ S0102-09352007000100034.

PASQUETTI, T. Avaliação nutricional da glicerina bruta ou semipurificada, oriundas de gordura animal e óleo vegetal, para codornas de corte. 2011. 110f. Dissertação (Mestrado em Zootecnia) - Curso de Pós-graduação em Zootecnia, Universidade Estadual de Maringá, PR.
ROSTAGNO, H.S. et al. Tabelas brasileiras para aves e suínos. Composição de alimentos e exigências nutricionais. Viçosa: UFV, 2011. 1v.

SAKOMURA, N.K. et al. Efeito do nível de energia metabolizável da dieta no desempenho e metabolismo energético de frangos de corte. Revista Brasileira de Zootecnia, v.33, n.6, p.1758-1767, 2004. Available from: <http://www.scielo.br/pdf/rbz/v33n6s1/ a14336s1.pdf>. Accessed: Mar. 04, 2013. doi: 10.1590/S151635982004000700014 .

SCHERER, C. Exigência de energia metabolizável, lisina e metionina+cistina digestíveis para codornas de corte em fase de crescimento. 2009. 130f. Tese (Doutorado em Zootecnia) - Curso de Pós-graduação em Zootecnia, Universidade Estadual de Maringá, PR.

SCHERER, C. et al. Exigência de energia metabolizável de codornas de corte no período de 1 a 14 dias de idade. Revista Brasileira de Zootecnia, v.40, n.11, p.2496-2501, 2011. Available from: <http://www.scielo.br/pdf/rbz/v40n11/30.pdf >. Accessed: Mar. 04, 2013. doi: 10.1590/S1516-35982011001100030.

SILVA, J.H.V. et al. Exigências nutricionais de codornas. In: SIMPÓSIO INTERNACIONAL DE COTURNICULTURA, 3., 2007, Lavras, MG. Anais... Lavras: Universidade Federal de Lavras, 2007. p.44-64.

SILVA, J.H.V.; COSTA, F.G.P. Tabela para codornas japonesas e europeias. Jaboticabal: editora Funep, 2009. 1v.

SILVA, D.J.; QUEIROZ, A.C. Análises de alimentos: métodos químicos e biológicos. Viçosa: Minas Gerais, 2004. 3v.

TEIXEIRA, B.B. et al. Desempenho de codornas de corte submetidas a diferentes níveis de proteína bruta e energia metabolizável. Ciência Rural, v.43, n.3, p.524-529, 2013. Available from: $<$ http:// www.scielo.br/pdf/cr/v43n3/a7013cr6709.pdf $>$. Accessed: Sept. 13, 2015. doi: 10.1590/S0103-84782013005000014.

TON, A.P.S. et al. Exigências de lisina digestível e de energia metabolizável para codornas de corte em crescimento. Revista Brasileira de Zootecnia, v.40, n.3, p.593-601, 2011. Available from: <http://www.scielo.br/pdf/rbz/v40n3/18.pdf>. Accessed: Mar. 03, 2013. doi: 10.1590/S1516-35982011000300018.

TON, A.P.S. Exigências de lisina digestível e energia metabolizável de codornas de corte (coturnix coturnix sp.) em crescimento, com base no conceito de proteína ideal. 2007. 56f. Tese (Mestrado em Zootecnia) - Curso de Pós-graduação em Zootecnia, Universidade Estadual de Maringá, PR.

UNIVERSIDADE FEDERAL DE VIÇOSA. Sistema para análises estatísticas e genéticas - SAEG, versão 9.1. Viçosa: Fundação Arthur Bernardes, 2007. (CD-ROM).

VELOSO, R.C. et al. Níveis de proteína bruta e energia metabolizável em uma linhagem de codorna de corte. Acta Scientiarum. Animal Sciences, v.34, n.2, p.169-174, 2012. Available from: <http://www. scielo.br/pdf/asas/v34n2/a10v34n2.pdf>. Accessed: Mar. 02, 2013. doi: 10.4025/actascianimsci.v34i2.12589.

WALDROUP, P.W. Nutrient requirement of broilers. In: SIMPÓSIO INTERNACIONAL SOBRE EXIGÊNCIAS NUTRICIONAIS DE AVES E SUÍNOS, 1996, Viçosa, MG. Anais... Viçosa, MG: Universidade Federal de Viçosa, 1996. V.1. p.57. 